\title{
Neuroprotective effect of creatine against propionic acid toxicity in neuroblastoma SH-SY5Y cells in culture
}

\author{
Afaf El-Ansary*, Ghada Abu-Shmais and Abeer Al-Dbass \\ Biochemistry Department, College of Science, King Saud University, P.O. Box 22452, Zip code 11495, Riyadh, Saudi \\ Arabia.
}

Accepted 15 March, 2013

\begin{abstract}
This work aimed to verify propionic acid toxic effects, and to investigate the possible neuroprotective effects of creatine against it. Propionic acid (PA) toxicity together with the effect of creatine (CR) was studied on neuroblastoma SH-SY5Y brain cells in culture. In the first group, cells were divided and treated with different concentrations of PA, while the second group was pre-treated with creatine to test its neuroprotective effect in PA-intoxicated cells. Comet assay and DNA fragmentation studies were used to examine genotoxicity and apoptosis of cells. The results emphasized the neurotoxicity of propionate to neuroblastoma cell line SH-SY5Y by DNA fragmentation that increased in a dose- and time-dependent manner. More importantly, our data confirms a possible neuroprotective effect of creatine against the neurotoxic effect of propionic acid. The obtained in vitro data supports and explains the in vivo neurotoxic effect of PA and proves its DNA damaging effect which could clarify its role in the etiology of autism, a phenomenon recently raised by many researchers. It also supported the accumulating literature which describes creatine as a potential bioactive agent against neurotoxicity. With sufficient research and clinical trials in future, this could prove to be successful in treatment or management of autism as a neurodevelopmental disorder recently related to PA neurotoxicity.
\end{abstract}

Key words: Propionic acid, creatine, SH-SY5Y, comet assay, DNA fragmentation assay, apoptosis, neuroprotection.

\section{INTRODUCTION}

Propionic acid (PA) is a short chain fatty acid that is dietary obtained (Zarate et al., 2004), or naturally produced in cellular metabolism (Thompson et al., 1990). PA is thought to be involved in behavioral and neuropathological abnormalities reported in some neurological conditions (Wajner et al., 2004). The chemical properties of this weak acid facilitate its easy access to the brain; where it can accumulate, leading to intracellular acidification (Bonnet et al., 2000). These facts sugges that central nervous system (CNS) is sensitive to high PA levels (Brusque et al., 1999).

Propionic acidemia is well-recognized as a genetic neu- rodevelopmental metabolic disorder, characterized by elevated PA accompanied by developmental delay and various neurological and behavioral manifestations (Feliz et al., 2003). PA neurotoxicity develops from consequent alterations at many levels, like metabolism (Brass and Beyerinck 1988), inflammatory response (Cavaglieri et al., 2003), and neurotransmission (Cannizzaro et al., 2003).

There has been a growing interest on possible environmental agents involved in the aetiology of autism as a neurodevelopmental disorder of increasing prevalence, such as chemical toxins, which could act during critical periods of pre- and early postnatal development (Lawler 
et al., 2004). Of particular relevance to this argument, propionic acid (PA) has often been reported to induce a number of behavioral changes and neuroinflammatory responses in rats reminiscent of autism spectrum disorder (ASD) (El-Ansary et al., 2012). This dietary short chain fatty acid is a common food preservative and metabolic endproduct of enteric bacteria in the gut. Although mostly accumulating in the gut, PA can readily cross the gut-blood and blood-brain barriers (BBB) and gain access to the CNS. In the brain, it can cross cell membranes and accumulate within cells, inducing intracellular acidification (Bonnet et al., 2000, Karuri et al., 1993), which may alter neurotransmitter releases and, ultimately, neuronal communication and behavior (Cannizzaro et al., 2003, Severson et al., 2003). MacFabe et al. (2007) showed that intraventricular infusion of PA can change both brain and behavior in the laboratory rat in a manner that is consistent with symptoms of human ASD. The behavioral, neuropathological and biochemical findings in the MacFabe's PA model provide further support the hypothesis that autism may be a systemic metabolic encephalopathic process affecting the brain. They have also found evidence of reversible impairments in social behavior following PA exposure (Shultz et al., 2008). This was ascertained through the recent work of El-Ansary et al. (2011b) in which they proved the efficacy of omega-3 fatty acids to protect against PA-induced neurotoxicity in rat pups.

The derivative, 3-nitropropionic acid (3-NP), has also been associated with neuronal degeneration, cytotoxicity, and various brain lesions (He et al., 1995; Ryu et al., 2003). PA and 3-NP are receiving lots of interest in development of in vitro and animal models for better understanding of neurological conditions like Huntington's disease (HD) (Borlongan et al., 1997) and autism (MacFabe et al., 2007). Discoveries of promising neuroprotective agents have urged the need for such studies to investigate the possibilities (Alexi et al., 2000).

Among the promising neuroprotectors is creatine (CR) ( $\mathrm{N}$-aminoiminomethyl-N-methylglycine), a natural guanidino compound that can be dietary obtained or endogenously synthesized. The brain can synthesize its own $\mathrm{CR}$ or take it up from circulation by specific creatine transporters (CRTs) (Braissant et al., 2001). In neural cells, CR is charged-up to phosphocreatine $(\mathrm{PCr})$ by creatine kinase (CK), and excess is degraded to createnine (Wyss and Kaddurah-Daouk, 2000).

The critical role of $\mathrm{CR}$ and $\mathrm{PCr}$ in maintaining energy requirements as components of the $\mathrm{CK}$ system is well established. However, CR is thought to have additional important functions and neuroprotective roles in the CNS (review Andres et al., 2008). Recent in vitro findings suggested that $C R$ helps to protect neurons against hyperammonemia and hyper-osmotic shock (Bachmann et al., 2004; Alfieri et al., 2006). A direct anti-apoptotic effect for $\mathrm{CR}$ and functions as direct antioxidant have been reported (Lawler et al., 2002; Dolder et al., 2003). There is a strong evidence for $\mathrm{CR}$ role as a neuromodulator (Almeida et al., 2006), and its administration exerted positive effects on mental performance (Rae et al., 2003). $\mathrm{PCr}$ can stimulate synaptic glutamate uptake to prevent excitotoxicity (Xu et al., 1996). All these protective effects have urged researchers to investigate $\mathrm{CR}$ as a possible neuroprotector against various toxins (including 3-NP) used in neuropathological in vitro and in vivo models (Brewer and Wallimann 2000; Shear et al., 2000; Berger et al., 2004; Vis et al., 2004; Andres et al., 2005; Heitz et al., 2008).

CR administration has proven to be protective of neural, cardiac and muscular tissue in a variety of pathogenic conditions. A creatine-supplemented diet signifcantly improved neuronal survival in rats administered malonate or 3-NP to deplete succinate dehydrogenase and mimic the pathophysiology of HD (Matthews et al., 1998). In Parkinsonian mice produced by N-methyl-4phenyl-1,2,3,6-tetrahydropyridine (MPTP) exposure, oral supplementation with creatine or cyclocreatine showed marked improvement of dopamine levels and survival of substantia nigra neurons (Matthews et al., 1999).

This work aimed to verify the in vitro DNA damaging effects of PA on neuroblastoma cells, and to investigate possible antagonism of $\mathrm{CR}$ as a promising neuroprotective effecter.

\section{MATERIALS AND METHODS}

\section{Cell culture}

Human neuroblastoma cell line SH-SY5Y, purchased from American Type Tissue Culture (ATTC; Manassas, VA), were cultured in Dulbecco's Modified Eagles Medium (DMEM), supplemented with $15 \%$ fetal bovine serum (FBS), $2 \mathrm{mM} \mathrm{L}$-glutamine, $1000 \mathrm{mg} / \mathrm{ml}$ (high glucose) D-glucose, $1 \%$ non-essential amino acids, $100 \mathrm{U} / \mathrm{ml}$ Penicillin, and $100 \mu \mathrm{g} / \mathrm{ml}$ Streptomycin, in a $95 \%$ air and $5 \% \mathrm{CO}_{2-}$ humidified incubator at $37^{\circ} \mathrm{C}$. They were grown in T-25 flasks until 70 to $80 \%$ confluence, and then split for sub-culturing (Encinas et al., 2002; Ryu et al., 2003; Constantinescu et al., 2007; Yang et al., 2009).

\section{Treatments}

To study propionic acid (PA) toxicity and the effect of creatine on it, the brain cells were divided into two groups. In the first group, cells were divided and treated with different concentrations of PA, which was added to the culture media to reach the final concentrations $(0$, 5 and $10 \mathrm{mM}$ ). This group was used for studying the effects of PA toxicity (Ryu et al., 2003).

The second group of cells was used to study the possible neuroprotective effects of creatine (CR) against PA toxicity. Those cells were divided and pretreated with different concentrations of $\mathrm{CR}$, which was dissolved in the media to reach final concentrations $(0$, 12 and $24 \mathrm{mM}$ ) (Vis et al., 2004). CR-pretreated cells were subdivided and followed by PA treatments $(0,5$ and $10 \mathrm{mM})$. Cells with zero PA and zero CR served as the control group for the entire study. Cells with zero PA were used to show the effects of CR treatment on healthy cells without the PA toxicity. Finally, cells with zero $\mathrm{CR}$ were used to study the toxic effects of PA on brain cells. To study the effect of CR against PA, the rest of the cells were treated 
with both CR and PA; for each of group of cells, two different concentrations of CR were used (12 and $24 \mathrm{mM}$ ). Studying CR effect against PA, also allowed us to monitor the effect of dose increase for each of $\mathrm{CR}$ and PA. The effects of treatments were examined after 24 and $48 \mathrm{~h}$ of incubation at $37^{\circ} \mathrm{C}, 95 \%$ air and $5 \% \mathrm{CO}_{2}$ atmosphere.

\section{Single cell gel electrophoresis (comet assay)}

From each group of cells, slides were prepared for a standard comet assay as described originally by Singh et al. (1988). About 4 $X 10^{6}$ cells were mixed with $80 \mu \mathrm{l}$ of $0.7 \%$ low-melting agarose in phosphate-buffered saline (PBS) at $37^{\circ} \mathrm{C}$ in a microtube, and then spread over a window microscopic slide. The slides were precoated with $150 \mu \mathrm{l}$ of $0.5 \%$ normal-melting agarose in PBS, and were specially designed for this assay. Then, slides were placed immediately in cold lysis buffer, $2.5 \mathrm{M}$ sodium chloride $\mathrm{NaCl}, 100 \mathrm{mM}$ ethylenediamine-tetraacetic acid sodium salt $\mathrm{Na}_{2}$ EDTA, $10 \mathrm{mM}$ Tris $(\mathrm{pH} 10)$, and $1 \%$ Triton $\mathrm{X}-100$, at $4^{\circ} \mathrm{C}$ for a minimal of $1 \mathrm{~h}$. After lysis, the slides were drained and placed in a horizontal gel electrophoresis tank surrounded by ice, and filled with fresh cold electrophoresis buffer (300 mM sodium hydroxide $\mathrm{NaOH}, 1 \mathrm{mM} \mathrm{NaEDTA}, \mathrm{pH}$ 13). To allow DNA unwinding, the slides were kept in the high $\mathrm{pH}$ buffer for $20 \mathrm{~min}$. After that, electrophoresis was carried out for $20 \mathrm{~min}$ at $25 \mathrm{~V}$ and $300 \mathrm{~mA}$. The slides were then drained and flooded slowly with three changes of neutralization buffer $(0.4 \mathrm{M}$ Tris, $\mathrm{pH} 7.5)$ for 5 min each, and then stained with $30 \mathrm{ml}$ of ethidium bromide (20 $\mathrm{mg} / \mathrm{l})$, and covered with cover slips. All those steps were performed under dimmed light in order to prevent additional DNA damage caused by visible light. A total of 50 randomly selected cells per slide were analyzed. Imaging was done using a fluorescence microscope (Zeiss Axiovert L410 Inc., Jena Germany), attached to a digital camera (Olympus Inc., Tokyo, Japan), and equipped with $549 \mathrm{~nm}$ excitation filter, $590 \mathrm{~nm}$ barrier filter, and a 100-W mercury lamp. The percentage of DNA in the comet tail "DNA damage" was automatically calculated (Trice et al., 2000).

\section{DNA fragmentation}

The method described by Chaudhary et al. (2001) was used for DNA extraction and agarose gel electrophoresis. After 24 and $48 \mathrm{~h}$ of treatment, both attached and floating cells were collected, washed with PBS, and centrifuged at $1500 \mathrm{rpm}$ for $5 \mathrm{~min}$ to precipitate the cells. The cell pellet was resuspended in $0.5 \mathrm{ml}$ of lysis buffer, transferred to a microfuge tube and incubated for $1 \mathrm{~h}$ at $37^{\circ} \mathrm{C}$. Then, $4 \mu \mathrm{l}$ of proteinase $\mathrm{K}$ was added to the tubes, and they were incubated at $50^{\circ} \mathrm{C}$ for $3 \mathrm{~h}$. To separate the DNA, phenolchloroform extraction was carried out by adding $0.5 \mathrm{ml}$ of phenol: chloroform: isoamyl alcohol $(25: 24: 1)$ to each tube with mixing and centrifugation at 13,000 rpm for $1 \mathrm{~min}$. The extraction was repeated twice, followed by chloroform extraction alone. The resulting DNA containing upper aqueous phase was separated, and to that, two volumes of ice-cold absolute ethanol and 1/10th volume of $3 \mathrm{M}$ sodium acetate were added, followed by incubation on ice for 30 min to precipitate the DNA. Centrifugation at 13,000 rpm for $10 \mathrm{~min}$ at $4^{\circ} \mathrm{C}$ precipitated DNA pellets, which, after discarding the supernatant, was washed with $1 \mathrm{ml}$ of $70 \%$ ethanol. The centrifugation step was repeated to remove the last traces of the supernatant fraction. The pellet was allowed to dry at room temperature for approximately $30 \mathrm{~min}$, and resuspended in $50 \mu \mathrm{l}$ of Tris-EDTA buffer. DNA quantification was conducted using ultraviolet (UV) spectroscopy, and $10 \mu \mathrm{g}$ of DNA was electrophoresed in a $1.2 \%$ agarose gel, containing ethidium bromide, in a mini gel tank containing Tris-boric acid-EDTA buffer for $2 \mathrm{~h}$ under $90 \mathrm{~V}$, using a ready-to-use 100 bp DNA ladder (GenScript, USA). Finally, the gel was visualized under UV transilluminator (Chaudhary et al., 2001).

\section{Statistical analysis}

The Statistical Package for Social Sciences (SPSS) computer program was used. Results are expressed as mean \pm S.D. and all statistical comparisons were made by means of independent t-Test and $P \leq 0.05$ was considered significant.

\section{RESULTS AND DISCUSSION}

In this work, apoptosis detection techniques, that is, single cell gel electrophoresis (comet assay) and typical DNA fragmentation assay, were used to verify the neurotoxic effects of PA on neuroblastoma cell lines, and the antagonistic effects of creatine treatments. The results are presented in Figures 1, 2, 3, 4, 5, and 6.

Our results show increased DNA fragmentation in the PA-treated cells compared to control, which was clearly evident in the comet assay data and was supported by the DNA fragmentation ladder results. After $24 \mathrm{~h}$ of treatment with $5 \mathrm{mM} \mathrm{PA}$, the comet results (Figure 1) showed an increase in the DNA tail length for PA-treated cells $(2.442 \mu \mathrm{m})$ compared to the control $(0.541 \mu \mathrm{m})$, indicating the neurotoxic effect of PA as it caused increased nuclear DNA damage and fragmentation. This effect worked in a dose-dependent manner, whereby more increase in the tail length (to $7.794 \mu \mathrm{m}$ ) was observed following $24 \mathrm{~h}$ treatment with a higher dose of PA $(10 \mathrm{mM})$. Another factor that played a role in this matter is the incubation time following the treatments. Compared to the results after $24 \mathrm{~h}$, it was noticed that with the prolonging of incubation time to $48 \mathrm{~h}$, the PA neurotoxic effects manifested stronger. After $48 \mathrm{~h}$ (Figure 2 ), the tail length for cells treated with $5 \mathrm{mM} P A$ increased more $(3.525 \mu \mathrm{m})$, compared to the $24 \mathrm{~h}$ results $(2.442$ $\mu \mathrm{m})$ and control $(0.781 \mu \mathrm{m})$, with the same observation in those treated with the higher PA dose (to $13.013 \mu \mathrm{m}$ ).

The results of the study also confirms an antagonistic neuroprotective effect for creatine, demonstrated by decrease in the tail length $(\mu \mathrm{m})$ in the creatine-pretreated cells compared to PA-treated cells that were not exposed to creatine (Figure 3). The decreases in fragmented DNA $\%$ further support the results (Figure 4 ).

In cells that were pretreated with $12 \mathrm{mM}$ creatine, after $24 \mathrm{~h}$ incubation, the tail length decreased in the group treated with $5 \mathrm{mM}$ PA (from 2.442 to $2.095 \mu \mathrm{m}$ ), as well as the one treated with $10 \mathrm{mM}$ PA (from $7.794 \mu \mathrm{m}$ to $6.230 \mu \mathrm{m})$. This effect was dose-dependent, where a higher creatine dose $(24 \mathrm{mM})$ caused further decrease in the tail length for both $5 \mathrm{mM}$ PA group (to $1.955 \mu \mathrm{m}$ ) and $10 \mathrm{mM}$ PA group (to $4.971 \mu \mathrm{m}$ ). Like the neurotoxic effect of PA, the neuroprotective effect of creatine also depended on the time of incubation following treatments.

After $48 \mathrm{~h}$, the effect of $12 \mathrm{mM}$ creatine pretreatment on decreasing PA-induced DNA fragmentation was enhanced in both $5 \mathrm{mM}$ PA (to $2.943 \mu \mathrm{m}$ ) and $10 \mathrm{mM}$ PA groups (to $10.401 \mu \mathrm{m}$ ). Similarly, the effect of $24 \mathrm{mM}$ creatine pretreatment was increased after $48 \mathrm{~h}$, decreesing DNA tail length further in the $5 \mathrm{mM}$ PA group 


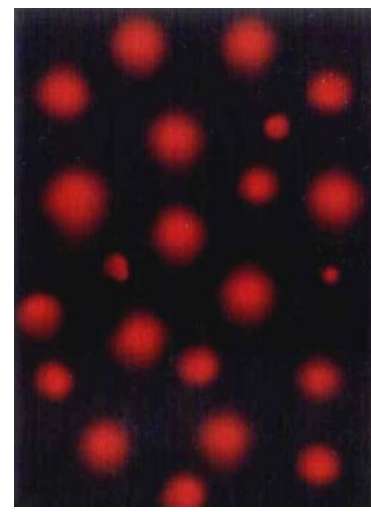

Control

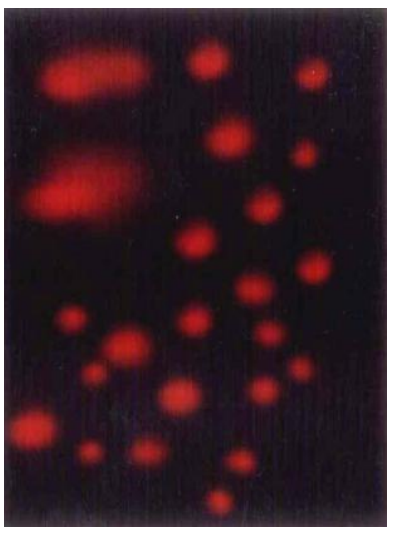

5 mM PA

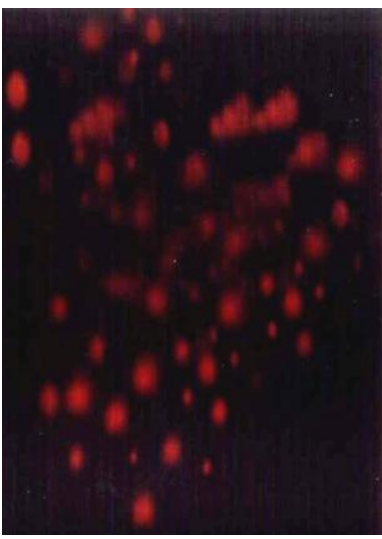

10 mM PA

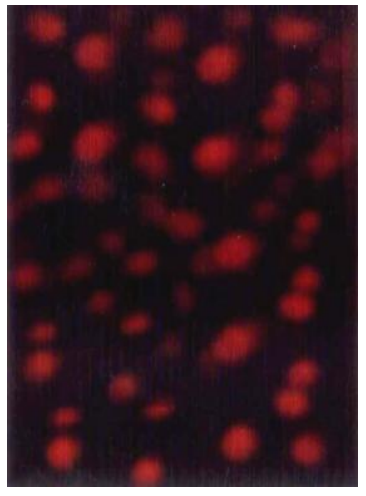

$12 \mathrm{mM}$ CR

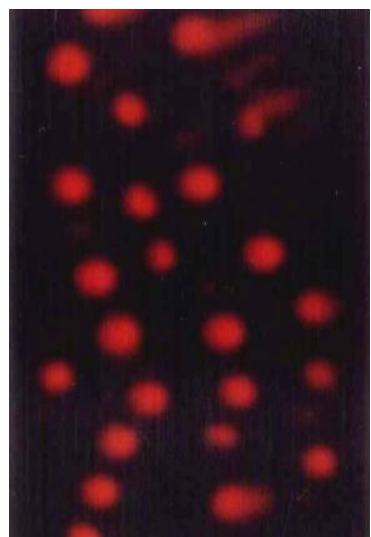

5 mM PA + 12 mM CR

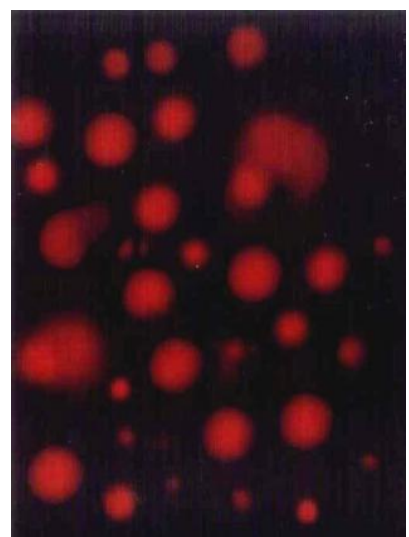

10 mM PA + 12 mM CR

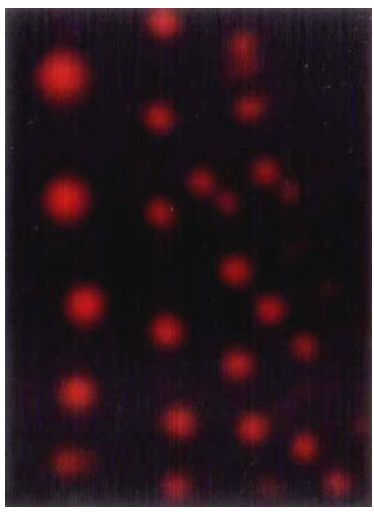

24 mM CR

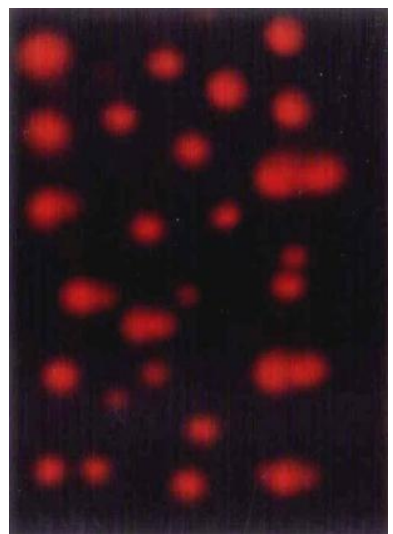

5 mM PA + 24 mM CR

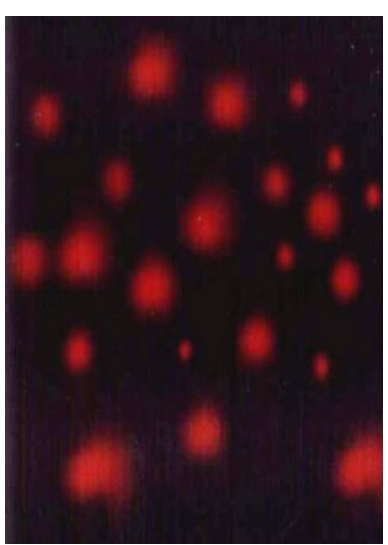

$10 \mathrm{mM} P A+24$ mM CR

Figure 1. Single cell gel electrophoresis (comet assay) images for neuroblastoma after $24 \mathrm{~h}$ exposure. SH-SY5Y cells were exposed to different concentrations of propionic acid (PA) (5 and $10 \mathrm{mM}$ ), in the presence and absence of creatine (CR) at different doses (12 and $24 \mathrm{mM})$ for 24 h. Images were taken using fluorescent microscope (Zeiss Axiovert L410, Germany) after staining the cells with ethidium bromide $(20 \mathrm{mg} / \mathrm{l})$.

(to $2.745 \mu \mathrm{m}$ ), as well as the $10 \mathrm{mM}$ PA one (to 8.300 $\mu \mathrm{m})$. Cells which were treated with a high dose of creatine (24 $\mathrm{mM}$ ) even showed less fragmentation than the control group, which emphasized its possible important neuroprotection role. The result of DNA ladder test emphasizes the results of the comet assay as PA caused DNA fragmentations in a dose and time dependent manner. The higher fragmentation within $24 \mathrm{~h}$ (Figure 5A) was caused by $10 \mathrm{mM}$ PA (5 lines of fragmentation; bands) and the lowest percentage of compact DNA (14.4 to $54.49 \%$ ) was 


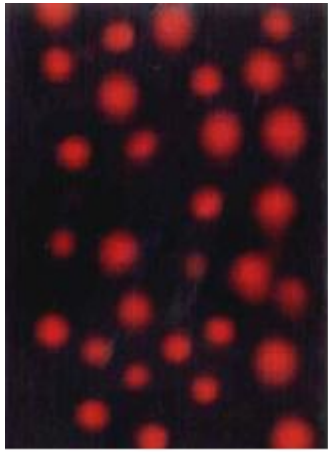

Control

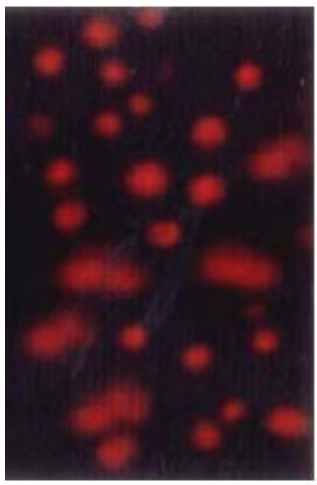

$5 \mathrm{mMPA}$

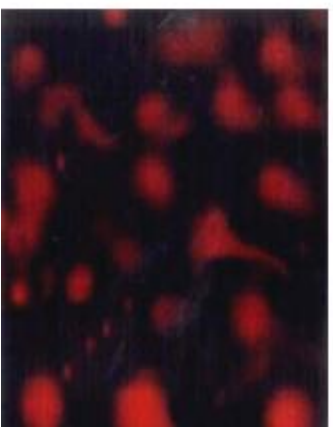

$10 \mathrm{mM}$ PA

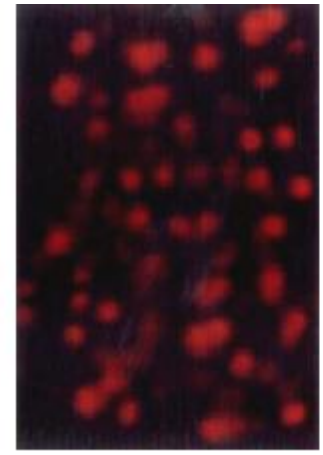

$12 \mathrm{mMCR}$

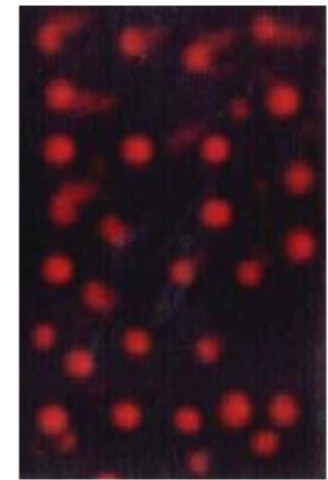

$5 \mathrm{mM} \mathrm{PA}+12 \mathrm{mMCR}$

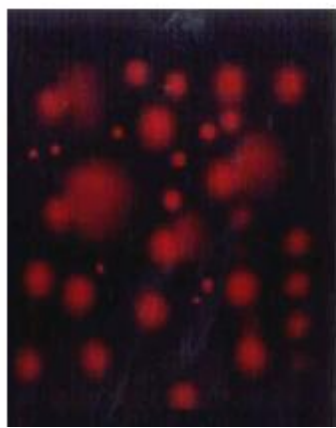

$10 \mathrm{mM} \mathrm{PA}+12 \mathrm{mM} \mathrm{CR}$

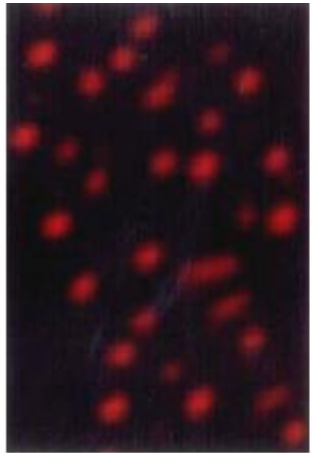

$24 \mathrm{mM} \mathrm{CR}$

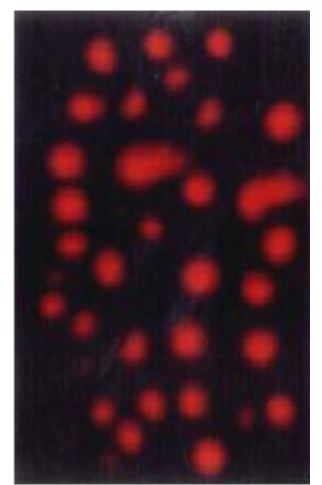

$5 \mathrm{mM} \mathrm{PA}+24 \mathrm{mM} \mathrm{CR}$

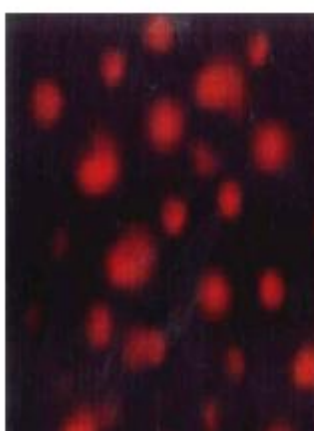

$10 \mathrm{mM} \mathrm{PA}+24 \mathrm{mM} \mathrm{CR}$

Figure 2. Single cell gel electrophoresis (comet assay) images for neuroblastoma after $48 \mathrm{~h}$ exposure. SH-SY5Y cells were exposed to different concentrations of propionic acid (PA) (5 and $10 \mathrm{mM})$, in presence and absence of creatine (CR) at different doses (12 and $24 \mathrm{mM}$ ) for $48 \mathrm{~h}$. Images were taken using fluorescent microscope (Zeiss Axiovert L410, Germany) after staining the cells with ethidium bromide $(20 \mathrm{mg} / \mathrm{l})$.

found in cells treated with $10 \mathrm{mM} P A$. Within $48 \mathrm{~h}$ of exposure (Figure $5 \mathrm{~B}$ ), the higher fragmentation (8 lines of fragmentation; bands) and the lowest percentage of compact DNA (6.36 to $50.95 \%$ ) were caused by $10 \mathrm{mM}$ of PA as well.

In addition, the DNA ladder data supported the comet assay, confirming the positive effect of creatine in decreasing PA-induced DNA damage, which was evident either by decreasing the degree of fragmentation (number of bands, Figure 6), or by improving the percentage of com- pact DNA (Figure 7) in creatine pretreated cells.

Apoptosis is now recognized as a normal part of early brain development, as well as its possible role in aging, and its involvement in neuronal degeneration and the progress of neurodegenerative diseases. There are many stimuli that are capable of activating apoptosis in neurons, including: glutamate excitotoxicity, excessive calcium flux, mitochondrial dysfunction, and oxidative stress (Sastry and Rao, 2000). The mitochondrial toxin 3- NP and PA have been used to generate several in vitro and 


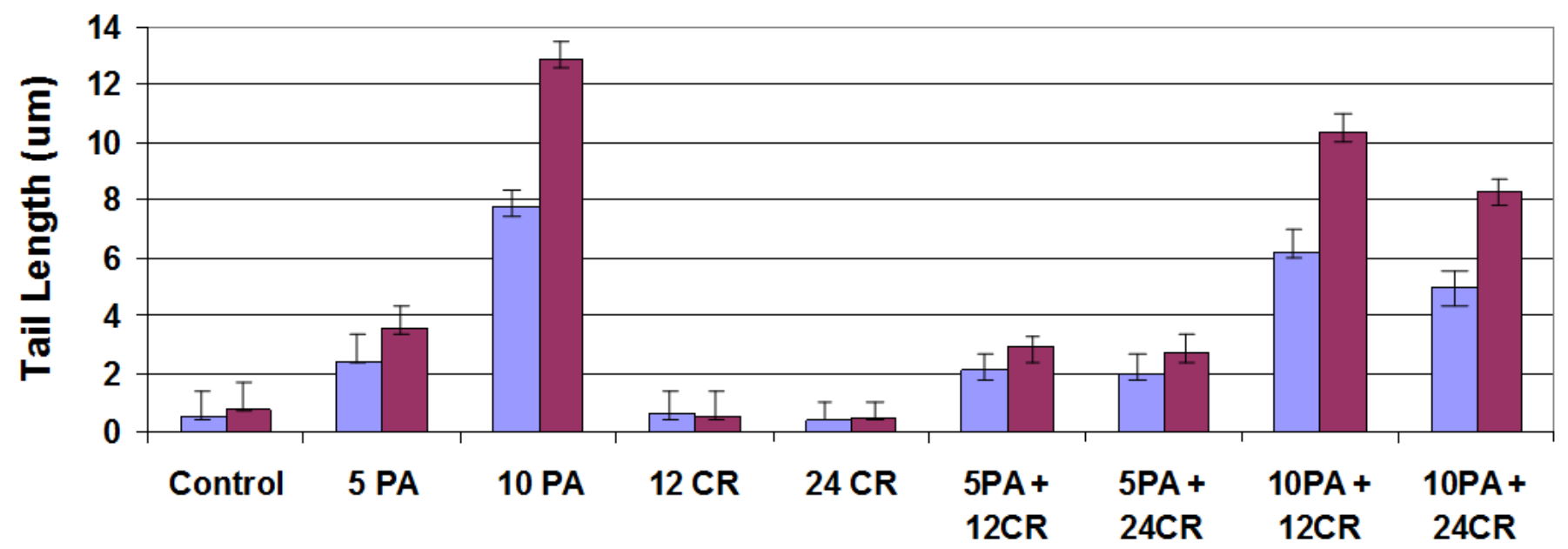

Treatment and Dose (mM)

$24 \mathrm{hr} \square 48 \mathrm{hr}$

Figure 3. Histogram showing the tail length calculated in $\mu \mathrm{m}$ for the neuroblastoma cells SH-SY5Y treated without and with different concentrations of propionic acid (PA) (5 and10 mM), in presence and absence of creatine (CR) at different doses (12 and $24 \mathrm{mM})$ for 24 and $48 \mathrm{~h}$. Tail lengths were measured using Comet Assay IV Ver. 4.3 (Perceptive Instruments Ltd., UK).

animal models for some neurological diseases such as HD. Through mitochondrial strain and increased oxidative stress, they could cause a host of downstream neurotoxic processes that leads to apoptotic and necrotic death after lesioning (Alexi et al., 2000). In accordance with this previous literature, our results confirm the neurotoxicity of PA that caused apoptotic DNA fragmentation in neuroblastoma cell line.

Creatine has been suggested to have a multifactorial neuroprotective effect, including several aspects, such as: anti-apoptosis, antioxidant, metabolic and energy regulation, neurotransmitters, and others. This has lead to suggest its possible beneficial role in some neurologic disorders, which was based on its protection against toxins in some in vitro and animal models (Andres et al., 2008, El-Ansary et al., 2011a).

Our results support the possible neuroprotection by $C R$ against PA, as indicated by the decrease in DNA fragmentation after CR treatment, which is supported by several previous studies. Increased neuronal survival and several neuroprotective effects for creatine administration have been observed in many in vitro experiments, in vivo models, and some clinical trials for some neurological diseases, such as: Huntington's (HD), Parkinson's (PD), and Alzheimer's diseases (AD), amyotrophic lateral sclerosis (ALS), hypoxic-ischemia, and stroke (Brewer and Wallimann 2000; Berger et al., 2004; Dupuis et al., 2004; Andres et al., 2005; Tabrizi 2005; Prass et al., 2007; Heitz et al., 2008). Among the models in some of these studies, along with other studies, creatine helped to attenuate 3-NP toxicity in neurons, astrocytes, or animal brain (Deshpande et al., 1997; Shear et al., 2000; Vis et al., 2004).
Andres et al. (2008) reviewed several studies regarding creatine and neurological diseases. As going through the available literature, CR seems promising as a neuroprotective agent for several neurological diseases which could greatly support the result of the present study. Biochemical analyses of brain homogenates from PA-treated rats showed mitochondrial dysfunction, impaired energy metabolism and brain excitotoxicity (decrease of $y$-aminobutyric acid (GABA) and increase glutamate as an inhibitory and excitatory neurotransmitters, respectively) as the main features of PA neurotoxicity (El-Ansary et al., 2012). This could help to suggest that the neuroprotective effects of creatine recorded in the present study could be explained on two integrated mechanisms. Firstly, creatine is effective in increasing cellular energy reserves which is critically needed to restore normal metabolite transport after being impaired by glutamate receptor-dependent excitotoxicity.

Secondly, due to the ability of creatine to slightly inhibit the mitochondrial permeability transition pore (MPTP), an early event in mitochondrial dysfunction is known to contribute to the apoptotic type of cell death observed with 3NP (Behrens et al., 1995, Pang and Geddes 1997) or the necrotic type of cell death associated with glutamate (Schinderetal., 1996, Dubinsky and Levi 1998, Brustovetsky and Dubinsky 2000). This suggested mechanism could be supported through considering the recent work of Genius et al. (2012) who reported that creatine effectively antagonized the hydrogen peroxide $\left(\mathrm{H}_{2} \mathrm{O}_{2}\right)$-induced ATP depletion and the excitotoxic response towards glutamate, while not directly acting as an antioxidant.

Transgenic rat and mouse models have now proved to be one of the most useful tools to understand the com- 


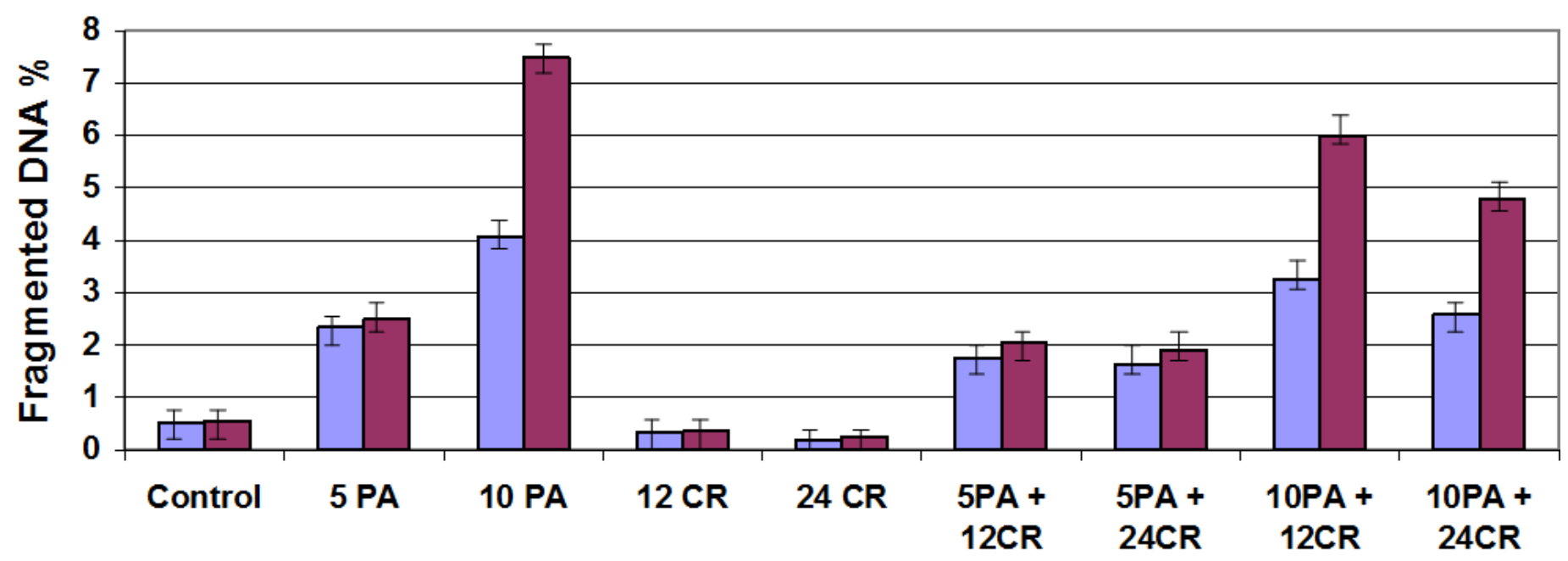

Treatment and Dose ( $\mathrm{mM})$

\section{$\square 24 \mathrm{hr} \square 48 \mathrm{hr}$}

Figure 4. Histogram showing the percentage of DNA damage incurred by the treatment of neuroblastoma cells $\mathrm{SH}-\mathrm{SY} 5 \mathrm{Y}$ with and without different concentrations of propionic acid (PA) $(5$ and $10 \mathrm{mM})$, in presence and absence of creatine (CR) at different doses (12 and $24 \mathrm{mM})$ for 24 and $48 \mathrm{~h}$. The percentage of DNA damage was automatically calculated by the DNA tail length and the distribution of the DNA in the tail called tail moments as described by Tice et al. (2000). Comet assay IV Ver. 4.3 (Perceptive Instruments Ltd., UK) was used for calculations.

plexity of neurodegenerative disease, such as Huntington's disease, Parkinson's disease, Alzheimer's disease, amyotrophic lateral sclerosis (ALS). They are also extremely useful in evaluating new therapeutics. Several years ago, Ferrante et al. (2000) and Zhang et al. (2003) administered creatine orally at various doses ( 1 and $2 \%$ of diet) to the mouse model of Huntington's and ALS. Interestingly, they found that creatine chronically administered before clinical disease onset could substantially delay onset of disease and prolong survival of the mice. It also delayed degeneration of motor neurons. For this reason, groups around the world soon began trials of using creatine in ALS. Although, the mouse trials suggested the effectiveness of creatine, unfortunately, human trials using creatine were unsuccessful (Rothstein, 2003). The most obvious answer for this failed human trial is that all preclinical models inherently have certain limitations. The culture models typically reflected immature, embryonic, or young postnatal motor neurons that are essentially on a short path to death (cultured motor neurons only survive a few weeks in vitro), and, also they are devoid of their neighbours as astrocytes, oligodendroglia, or microglia. This could help to suggest that in most of neurodegenerative diseases neurons do not die alone (Gong et al., 2000; Lino et al., 2002, Raoul et al., 2002). It appears that surrounding neurophil (microglia, astrocytes and possible other cells) all contribute to and are essential for the death of motor neurons. Even the neurodegenerative transgenic rodents have limitations.

First and the most important consideration when plan- ning human trials is the dose equivalent. Therefore, failure of human trials using creatine does not oppose its neuroprotective effects but there are several variables that one has to consider when making these human trials. Among this is the use of different drug concentrations and at different times of drug delivery (before clinical disease onset, at disease onset, and after disease begins in the mice). Ideally, all of these variables should be evaluated before starting a human trial, but they are not all practical and economically feasible.

With the limited researches, important unsolved questions regarding the dose and mechanism of action for creatine neuroprotection remains. However, it is still promising as a neuroprotective agent for further studies in the future, involving neurological and psychological diseases. More follow-up studies and trials on a larger scale are necessary in order to establish the optimum dose, and assess its effects on human subjects (Andres et al., 2008). Based on the present study together with selected previous in vivo studies, the protective effect of creatine seems to be related to its potency in maintaining mitochondrial bioenergetics. Increase of mitochondrial membrane potential, decrease of intra-mitochondrial levels of reactive oxygen species and calcium, together with the maintenance of adenosine triphosphate (ATP), ATP/ADP and $\mathrm{PCr} / \mathrm{Cr}$ levels were reported as mechanistic aspects of the protective effect of creatine (Klivenyi et al., 2004; Sullivan et al., 2000; El-Ansary et al., 2011a).

Most of the general therapies as vitamin $\mathrm{C}$, vitamin $\mathrm{E}$, glutathione, Coenzyme $Q$, creatine and idebenone are 
(A

$24 \mathrm{~h}$ exposure

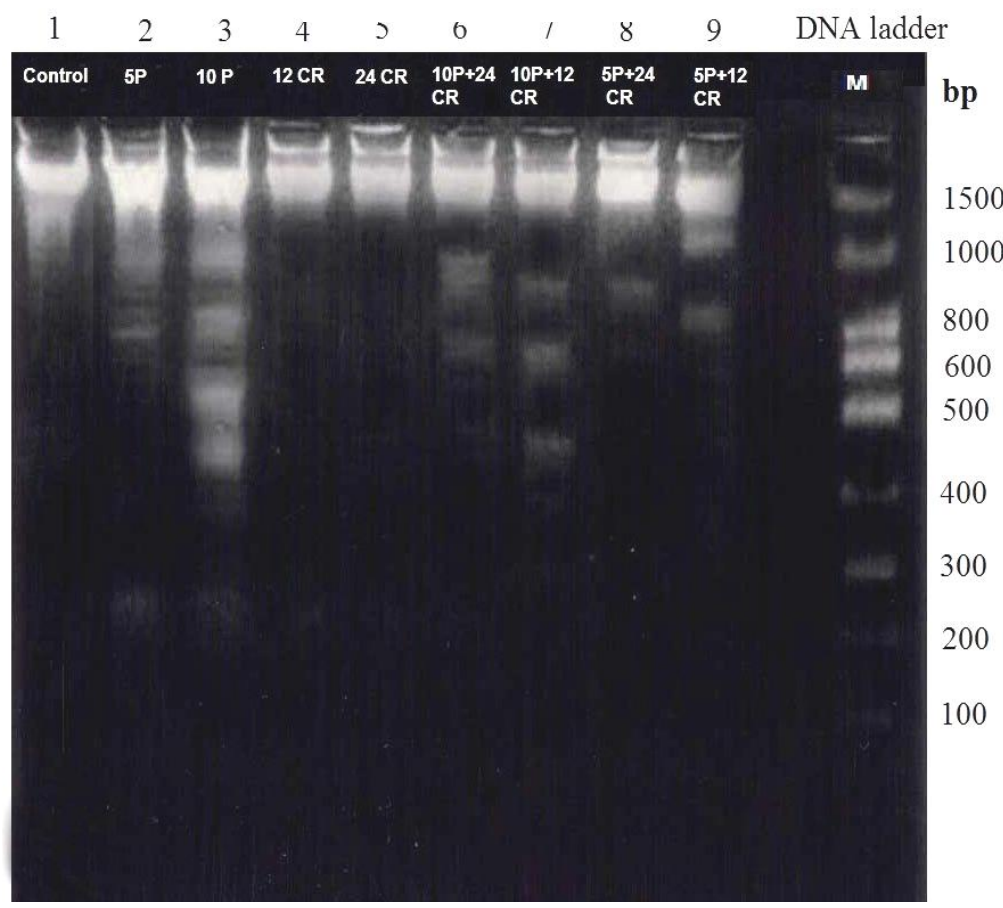

$48 \mathrm{~h}$ exposure

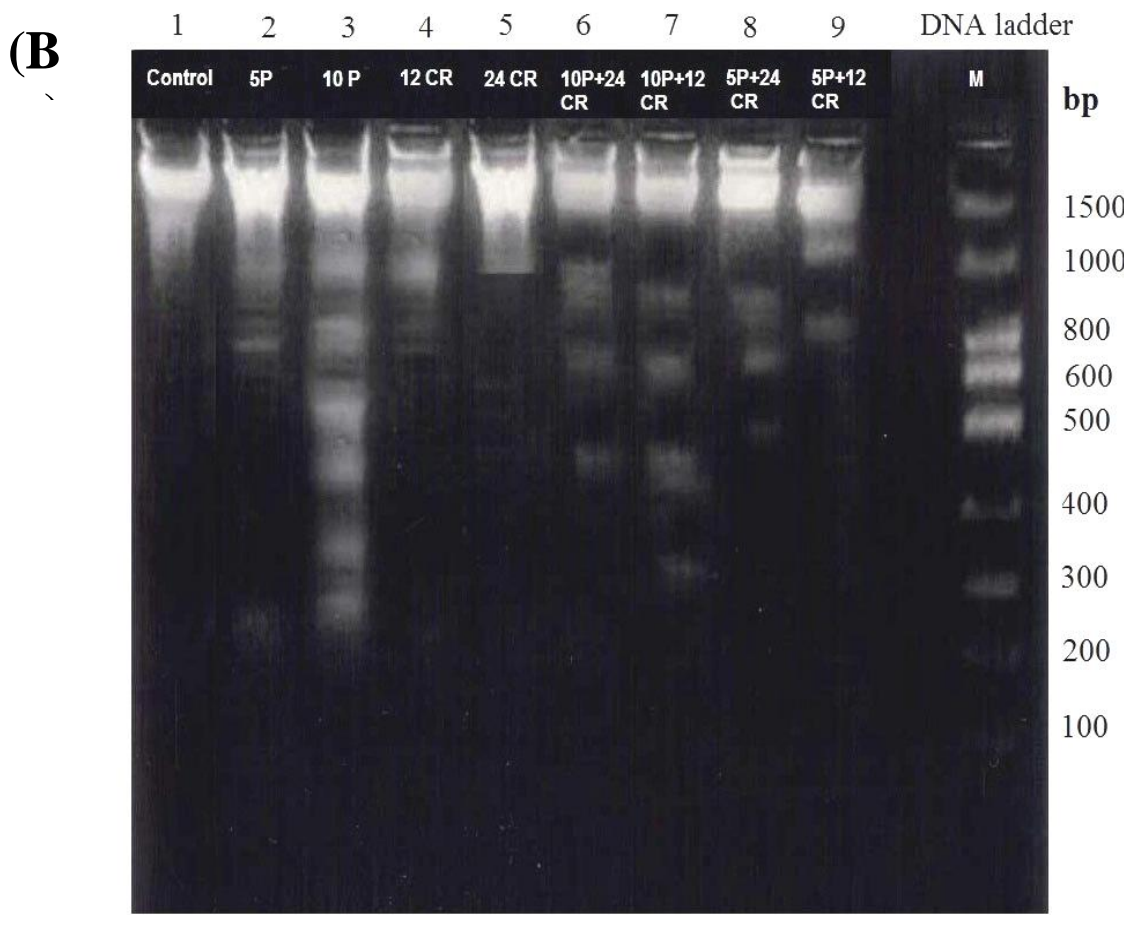

Figure 5. Images of the $1.2 \%$ agarose gel of genomic DNA extracted, following exposure of neuroblastoma cell SH-SY5Y for (A) $24 \mathrm{~h}$ and (B) $48 \mathrm{~h}$ with and without propionate $(P)$ in the presence and absence of creatine $(C R)$. Lane 1, DNA isolated from control cells; Lanes 2 and 3, SH-SY5Y cells treated with 5 and $10 \mathrm{mM}$ of P, respectively. Lanes 4 and 5, Cells treated with 12 and $24 \mathrm{mM}$ of CR alone. Lanes 6 and 7, Cells pretreated with 12 and $24 \mathrm{mM} \mathrm{CR}$ before $10 \mathrm{mM} P$ treatment. Lanes 8 and 9 are cells that were pretreated with 12 and $24 \mathrm{mM} \mathrm{CR}$ before $5 \mathrm{mM} \mathrm{P}$ treatment. Lane 10, 100 bp DNA ladder (GenScript, USA). 


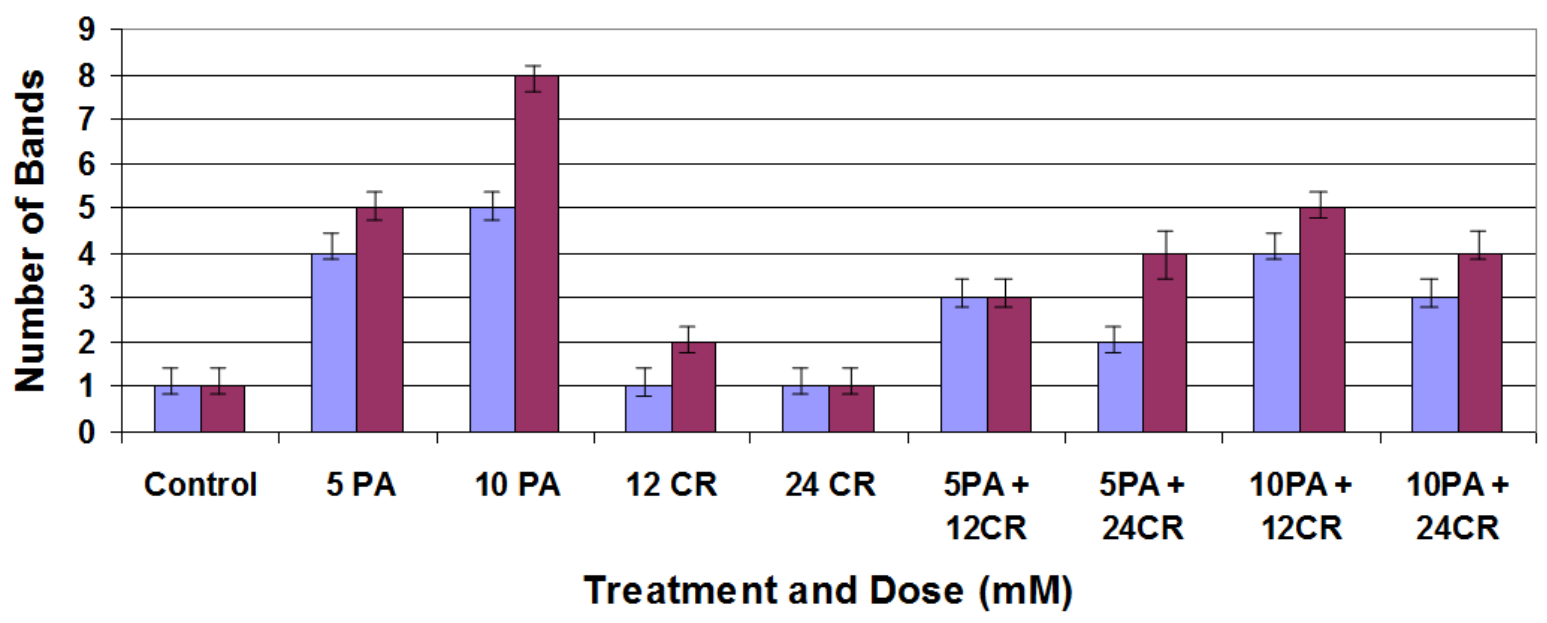

$\square 24 \mathrm{hr} \square 48 \mathrm{hr}$

Figure 6. Histogram showing the number of fragmented DNA bands obtained for the control and treated neuroblastoma cells SH-SY5Y. Neuroblastoma cells SH5Y were treated for 24 and $48 \mathrm{~h}$ without and with 5 and 10 $\mathrm{mM}$ PA in the presence and absence of creatine (CR) doses (12 and $24 \mathrm{mM}$ ). The genomic DNA were isolated from the above cells and run on $1.5 \%$ agaros gel electrophoresis, followed by staining with ethidium bromide and photographed under UV light. The number of fragmented bands was calculated by scanning the fluorescent DNA bands on the photograph of the gel using densitometer as described before.

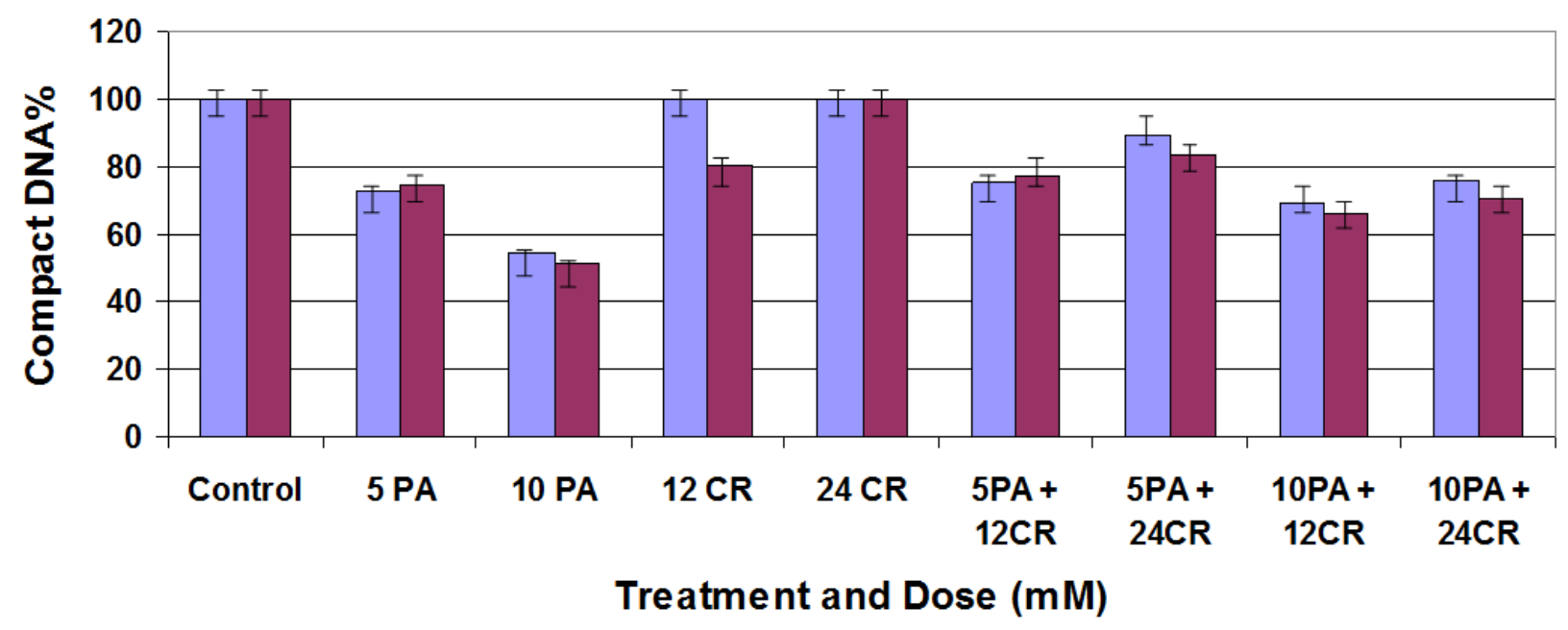

harmless at their usual doses, although some may be expensive. In the absence of any other proven therapy in mitochondrial disease, many clinicians resort, on theoretical or anecdotal grounds alone, to 'mitochondrial cocktails' of various combinations of these agents to treat their patients (Klopstockv et al., 2011).

\section{Conclusions}

In line with several previous studies, our results emphasize the neurotoxicity of PA, which was clearly seen through the increased DNA fragmentation in both comet assay and DNA ladder, indicating apoptotic activities in 
neuroblastoma that occurred in a time- and dose-dependent manner.

Our results confirm a possible protective effect for creatine on neuroblastoma, as it appears to attenuate PA- induced toxicity, as revealed by the decrease in DNA fragmentation in the cells pretreated with creatine, shown in both comet assay and DNA laddering. Creatine seems to be very promising as a neuroprotective agent. More experiments follow-up studies and clinical trials are necessary in the future.

\section{ACKNOWLEDGEMENTS}

This research project was supported by a grant from the Research Center of the Center for Female Scientific and Medical Colleges in King Saud University.

\section{REFERENCES}

Alexi T, Borlongan CV, Faull RL, Williams CE, Clark RG, Gluckman PD, Hughes PE (2000). Neuroprotective strategies for basal ganglia degeneration: Parkinson's and Huntington's diseases. Prog. Neurobiol, 60:409-470.

Alfieri RR, Bonelli MA, Cavazzoni A, Brigotti M, Fumarola C, Sestili P, Mozzoni P, De Palma G, Mutti A, Carnicelli D, Vacondio F, Silva C, Borghetti AF, Wheeler KP, Petronini PG (2006). Creatine as a compatible osmolyte in muscle cells exposed to hypertonic stress. J. Physiol. 576:391-401.

Almeida LS, Salomons GS, Hogenboom F, Jakobs C, Schoffelmeer AN (2006). Exocytotic release of creatine in rat brain. Synapse, 60:118123.

Andres RH, Ducray AD, Pérez-Bouza A, Schlattner U, Huber AW, Krebs SH, Seiler RW, Wallimann T, Widmer h. (2005). Creatine supplementation improves dopaminergic cell survival and protects against MPP+ toxicity in an organotypic tissue culture system. Cell Transplant, 14:537-550.

Andres RH, Ducray AD, Schlattner U, Wallimann T, Widmer $h(2008)$. Functions and Effects of Creatine in the Central Nervous System. Brain Res Bull, 76:329-343.

Bachmann C, Braissant O, Villard AM, Boulat O, Henry H (2004). Ammonia Toxicity to the Brain and Creatine. Mol. Genet. Metab. 81:52-57.

Behrens MI, Koh J, Canzoniero LM, Sensi SL, Csernansky CA (1995). 3-Nitropropionic acid induces apoptosis in cultured striatal and cortical neurons. Neuroreport. 6:545-548.

Berger R, Middelanis J, Vaihinger HM, Mies G (2004). Creatine protects the immature brain from hypoxic-ischemic injury. J. Soc. Gynecol Investig. 11:9-15.

Bonnet U, Bingmann D, Wiemann M (2000). Intracellular pH modulates spontaneous and epileptiform bioelectric cell coupling of hippocampal CA3-neurones. Eur Neuropsycho pharmacol. 10:97-103.

Borlongan CV, Koutouzis TK, Sanberg RP (1997). 3-Nitropropionic acid animal model and Huntington's disease. Neurosci Biobehav Rev. 21:289-293.

Braissant O, Henry H, Loup M, Eilers B (2001). Endogenous synthesis and transport of creatine in the rat brain: an in situ hybridization study. Brain Res. Mol. Brain Res. 86:193-201.

Brass EP, Beyerinck, RA (1988). Effects of propionate and carnitine on the hepatic oxidation of short- and medium-chain-length, fatty acids. Biochem. J. 250:819-825.

Brewer GJ., Wallimann TW ( 2000). Protective effect of the energy precursor creatine against toxicity of glutamate and beta-amyloid in rat hippocampal neurons. J. Neurochem. 74:1968-1978.

Brusque AM, Mello CF, Buchanan DN (1999). Effect of chemically induced propionic academia on neurobehavioral development of rats. Pharmacol. Biochem. Behav. 529:34-64.
Brustovetsky N, Dubinsky JM (2000). Dual responses of CNS mitochondria to elevated calcium. J. Neurosci. 20:103-113.

Cannizzaro C, Monastero R, Vacca M (2003). [3H]-DA release evoked by low $\mathrm{pH}$ medium and internal $\mathrm{Hp}$ accumulation in rat hypothalamic synaptosomes: involvement of calcium ions. Neurochem. Int. 43:917.

Cavaglieri CR, Nishiyama A, Fernandes LC, Curi R (2003). Differential effects of short-chain fatty acids on proliferation and production of pro- and anti-inflammatory cytokines by cultured lymphocytes. Life Sci. 7:1683-1690.

Chaudhary KS, Abel PD, Stamp GWH (2001). Differential expression of cell death regulators in response to thapsigargin and adriamycin in Bcl-2 transfected DU145 prostatic cancer cells. J. Pathol. 193:522529.

Constantinescu R, Constantinescu AT, Reichmann H, Janetzky B (2007). Neuronal differentiation and long-term culture of the human neuroblastoma line SH-SY5Y. J. Neural Transm. 72:17-28.

Deshpande SB, Fukuda A, Nishino H (1997). 3-Nitropropionic acid increases the intracellular $\mathrm{Ca} 2+$ in cultured astrocytes by reverse operation of the $\mathrm{Na}+\mathrm{Ca} 2+$ exchanger. Exp. Neurol. 14:38-45.

Dolder M, Walzel B, Speer O, Schlattner U (2003). Inhibition of the mitochondrial permeability transition by creatine kinase substrates Requirement for microcompartmentation. J. Biol. Chem. 278:1776017766.

Dubinsky JM, Levi Y (1998). Calcium-induced activation of the mitochondrial permeability transition in hippocampal neurons. J. Neurosci. Res. 53:728-741.

Dupuis L, Oudart H, F René F(2004). Evidence for defective energy homeostasis in amyotrophic lateral sclerosis: benefit of a high-energy diet in a transgenic mouse model. Proc. Natl. Acad. Sci. USA 101:11159-11164.

El-Ansary A., Nounou HA, Abdelzaher (2011a) Effectivness of creatine and cyclosporine to protect against propionic acid-induced neurotoxicity. Int. J. Pharmacol. Toxicol. Sci. 2:28-43.

El-Ansary A, Al-Daihan SK, and El-Gezeery AR (2011b) On the protective effect of omega-3 against propionic acid-induced neurotoxicity in rat pups. Lipids Health Dis. 10:142.

El-Ansary AK, Bacha AB, Kotb M (2012). Etiology of autistic features: the persisting neurotoxic effects of propionic acid. J. Neuroinflammation 9:74.

Encinas M, Iglesias M, Liu Y, Wang $H$, Muhaisen A, Ceña V, Carme Gallego C, Comella JX (2002). Sequential Treatment of SH-SY5Y Cells with Retinoic Acid and Brain-Derived Neurotrophic Factor Gives Rise to Fully Differentiated, Neurotrophic Factor-Dependent, Human Neuron-Like Cells. J. Neurochem. 75:991-1003.

Feliz R, Witt DR, Harris BT (2003). Propionic acidemia: a neuropathology case report and review of prior cases. Arch. Pathol. Lab. Med. 127:325-328.

Ferrante RJ ,Ole A. Andreassen OA, Jenkins BG, Dedeoglu A, Stefan K , Kubilus JK , Kaddurah-Daouk R ,Hersch SM, Beal MF (2000). Neuroprotective effects of creatine in a transgenic mouse model of Huntington's disease. J. Neurosci. 20:4389-4397.

Genius J, Geiger J, Bender A, Möller HJ, Klopstock T (2012). Creatine Protects against Excitoxicity in an In Vitro Model of Neurodegeneration. PLoS ONE, 7:30554-30561.

Gong YH, Parsadanian AS, Andreeva A, Snider WD, Elliott JL(2000). Restricted expression of G86R Cu/Zn superoxide dismutase in astrocytes results in astrocytosis but does not cause motoneuron degeneration. J. Neurosci. 20:660-665.

He F, Shoulin Zhang S, Qian F, Zhang C(1995). Delayed dystonia with striatal CT lucencies induced by a mycotoxin (3-nitropropionic acid). Neurol. 45:2178-2183.

Heitz F, La Rosa S, Gonzalez-Couto E, Gaviraghi G, Terstappen GC (2008). Drug discovery and development for Huntington's disease an orphan indication with high medical need. Drugs, 11:653-660.

Karuri AR, Dobrowsky E, Tannock IF (1993). Selective cellular acidification and toxicity of weak organic acids in an acidic microenvironment. Br. J. Cancer 68:1080-1087.

Klivenyi P, Calingasan NY, Starkov A, Stavrovskaya IG, Kristal BS, Yang L, Wieringa B, Beal MF. (2004) Neuroprotective mechanisms of creatine occur in the absence of mitochondrial creatine kinase. Neurobiol. Dis. 15(3):610-617. 
Klopstock T, Yu-Wai-Man P Dimitriadis K, Rouleau J, Heck S, Bailie $M$ (2011). A randomized placebo-controlled trial of idebenone in Leber's hereditary optic neuropathy. Brain 134:2677-2686.

Lawler JM, Barnes WS, Wu G, Song W (2002). Direct antioxidant properties of creatine. Biochem. Biophys. Res. Comm. 290:47-52.

Lawler CP, Croen LA, Grether JK, Van de Water J (2004). Identifying environmental contributions to autism: provocative clues and false leads. Ment. Retard. Dev. Disabil. Res. Rev. 10:292-302.

Lino MM, Schneider C, Caroni P (2002). Accumulation of SOD1 mutants in postnatal motoneurons does not cause motoneuron pathology or motoneuron disease. J. Neurosci. 22:4825-4832.

MacFabe DF, Cain DP, Rodriguez-Capote K, Franklin AE, Hoffman JE,Boon F, Taylor AR, Kavaliers M, Peter Ossenkopp K (2007). Neurobiological effects of intraventricular propionic acid in rats: possible role of short chain fatty acids on the pathogenesis and characteristics of autism spectrum disorders. Behav Brain Res. 176:149-169.

Matthews RT, Yang L, Jenkins BG, Ferrante RJ, Rosen BR, KaddurahDaouk R, FlintBeal M (1998). Neuroprotective effects of creatine and cyclocreatine in animal models of Huntington's disease. J. Neurosci, 18:156-163.

Matthews RT, Ferrante RJ, Klivenyi P, Yang L(1999). Creatine and cyclocreatine attenuate MPTP neurotoxicity. Exp Neurol, 157:142149.

Pang Z, Geddes JW (1997). Mechanisms of cell death induced by the mitochondrial toxin 3-nitropropionic acid: acute excitotoxic necrosis and delayed apoptosis. J Neurosci. 17:3064-3073.

Prass K, Royl G , Lindaue U, Freyer D, Megow D, Dirnagl U, StöcklerIpsiroglu G, Wallimann T, Priller J ( 2007). Improved reperfusion and neuroprotection by creatine in a mouse model of stroke. J. Cereb. Blood Flow Metab. 27: 452-459.

Rae C, Digney AL, McEwan AR, Bates TC (2003). Oral creatine monohydrate supplementation improves brain performance: a double-blind, placebo-controlled, cross-over trial. Proc. Biol. Sci. 270:2147-2150

Raoul C, Estévez AG, Nishimune H, Cleveland DW (2002). Motoneuron death triggered by a specific pathway downstream of Fas. Potentiation by ALS-linked SOD1 mutations. Neuron 35:1067-1083.

Rothstein JD (2003). Of Mice and Men: Reconciling Preclinical ALS Mouse Studies and Human Clinical Trials. Ann. Neurol. 53:423-426.

Ryu JK, Nagai A, Kim J, Lee MC, McLarnon JG, Kim SU(2003). Microglial Activation and Cell Death Induced by the Mitochondrial Toxin 3-Nitropropionic Acid: In Vitro and In Vivo Studies. Neurobiol. 12:121-132.

Sastry PS, Rao KS (2000). Apoptosis and the nervous system. J. Neurochem. 74:1-20.

Schinder AF, Olson EC, Spitzer NC, Monta M (1996). Mitochondrial dysfunction is a primary event in glutamate neurotoxicity. J. Neurosci. 16:6125-6133.

Severson CA, Wang W, Pieribone VA, Dohle CI, Richerson GB (2003). Midbrain serotonergic receptors neurons are central $\mathrm{pH}$ chemoreceptors. Nat. Neurosci. 6:1139-1140.

Shear DA, Haik KL, Dunbar GL (2000). Creatine reduces 3-nitropropionic- acid induced cognitive and motor abnormalities in rats. Neuro. Report 11:1833-1837.
Shultz SR, MacFabe DF, Ossenkopp KP, Scratch S, Whelan J, Taylor $\mathrm{R}$, et al. (2008). Intracerebroventricular injection of propionic acid, an enteric bacterial metabolic endproduct, impairs social behavior in the rat: implications for an animal model of autism. Neuropharmacol. 54:901-911.

Singh NP, McCoy MT, Tice RR, Schneider EL (1988). A simple technique for quantitation of low levels of DNA damage in individual cells. Exp. cell Res. 175:184-191.

Sullivan PG, Geiger JD, Mattson MP, Scheff SW., Sanders-Brown (2000). Dietary supplement creatine protects against traumatic brain injury. Ann. Neurol. 48(5):723-9.

Tabrizi SJ, Blamire AM, Manners DN, Rajagopalan B et al (2005). High-dose creatine therapy for Huntington disease: a 2-year clinical and MRS study. Neurol. 64:1655-1656.

Thompson GN, Walter JH, Bresson JL, Ford GC, Lyonnet SL, Chalmers RA, Saudubray JM, Leonard JV, Halliday D (1990). Sources of propionate in inborn errors of propionate metabolism. Metabolism 39:1133-1137.

Tice RR, Agurell E, Anderson D, Burlinson B, Hartmann A, Kobayashi H, Miyamae Y, Rojas E, Ryu JC, Sasaki YF (2000). Single Cell Gel/Comet Assay: Guidelines for In Vitro and In Vivo Genetic Toxicology Testing. Environ. Mol. Mutagen 35:206-221.

Vis JC, de Boer-van Huizen RT, Verbeek MM (2004). Creatine Protects against 3 Nitropropionic Acid-Induced Cell Death in Murine Corticostriatal Slice Cultures. Brain Res. 1024:16-24.

Wajner M, Latini A, Wyse ATS, Dutra-Filho S (2004). The role of oxidative damage in the neuropathology of organic acidurias: insights from animal studies. J. Inherit. Metab. Dis. 27:427-448.

Wyss M, Kaddurah-Daouk R. (2000). Creatine and creatinine metabolism. Physiol. Rev. 80:1107-1213.

Xu CJ, Klunk WE, Kanfer JN, Xiong Q, Miller G, Pettegrew JW (1996). Phosphocreatine-dependent glutamate uptake by synaptic vesicles. A comparison with ATP-dependent glutamate uptake. J. Biol. Chem. 271:13435-13440.

Yang L, Calingasan NY, Thomas B, Chaturvedi RK (2009). Neuroprotective Effects of the Triterpenoid, CDDO Methyl Amide: A Potent Inducer of Nrf2-Mediated Transcription. PLoS One 4:5757-5769.

Zárate G, González S, Chaia AP (2004). Assessing survival of dairy propionibacteria in gastrointestinal conditions and adherence to intestinal epithelia. Methods Mol. Biol. 268:423-432.

Zhang W, Narayanan M, Friedlander RM (2003). Additive neuroprotective effects of minocycline with creatine in a mouse model of ALS. Ann. Neurol. 53:267-270. 